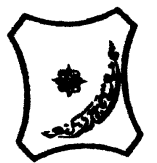

Bayero Journal of Pure and Applied Sciences, 5(1): 175 - 181

Received: October, 2011

Accepted: May, 2012

ISSN $2006-6996$

\title{
SOME ASPECTS OF THE GROWTH PARAMETERS OF THE FISHES OF IBRAHIM ADAMU LAKE, KAZAURE JIGAWA STATE, NIGERIA
}

\author{
*Sambo, F. ${ }^{1}$ and Haruna, M. $^{2}$ \\ ${ }^{1}$ Department of Forestry, Fisheries and Wild life Technology, College of Agriculture, Hadejia, Jigawa State. \\ ${ }^{2}$ Department of Biology, Kano University of Science and Technology, Wudil, Kano. \\ *Correspondence author
}

\begin{abstract}
The growth parameters and age for the fish species from the lake (O. niloticus, S. galilaeus and B. bayad) were computed through interpretation of marks found on their Opercula bones which were then fitted into Vonbertallanfy growth model. Their asymptotic length $(L \infty)$ ranged from $175 \mathrm{~mm}-$ $520 \mathrm{~nm}$. The growth performance index $\Phi^{\prime}$ ranged from $3.6622-4.9420$ and $K$ value from $0.10-$ 0.35 . 0 . niloticus $L \infty, K$ and $\Phi^{\prime}$ values ranged from $175 \mathrm{~mm}-192.5 \mathrm{~mm}, 0.15-0.25,3.6622-3.9668$ and were found to live up to $7^{+}$years in the lake. The values of $S$. galilaeus ranged from $200 \mathrm{~mm}-$ $240 \mathrm{~mm}, 0.12-0.17$ and $3.8211-3.8222$ and living up to $5^{+}$while $B$. bayad had a range of $500 \mathrm{~mm}$ $-520 \mathrm{~mm}, 0.10-0.35,4.4320-4.9420$ and lives up to $6+$ in the lake. All the growth parameters for the fish species were fitted into the Vonbertallanfy growth model.

$L_{t}=L \infty\left(i-{ }^{e}-k\left(t-t_{o}\right)\right.$
\end{abstract}

Keywords: Growth parameters, Age, Ibrahim Adamu Lake.

\section{INTRODUCTION}

Studies on the age and growth pattern play a very important role in fisheries management (Mohr, 1927). The studies on growth are components of fish stocks and are used to characterize the state of various fish populations. The method used is by counting the growth zones which appears on the hard parts of fishes, like the scales, opercula bones and otoliths. These marks are called annuli or rings and are formed during periods of faster and slower growth (Bilton, 1974). A lot of work has been done on the ageing of fishes. It includes those of Velaso et al., (1990); Getabu (1992); Patraki and Stergiou (1995); Jiminez et al., (2000); Ogueri, C., (2001); Doug, Darr (2008); Kumalo et al., (2010) and Gheslagi et al., (2012). The aim of the paper is to provide baseline information on the lake's fishes for better management.

\section{MATERIALS AND METHOD}

\section{a. Study Area}

Ibrahim Adamu Lake is located in Kazaure town of Jigawa State, $735 \mathrm{~km}$ from the State Capital Dutse on $13^{\circ}$ along the line of Latitude (Figure 1 ). The lake was constructed in 1974 with the primary aim of town water supply, irrigation, fisheries and secondary aim of recreation and wildlife conservation (WRECA, 1976).

\section{b. Sample Collection}

Sampling was carried out monthly for 24 months from October, 2003 - September, 2005 from different sampling stations (Figure 2) using different fishing gears viz: traps, cast nets of "2-10" mesh and hooks. The fish caught were placed on ice box and brought to the Research Laboratory immediately.

Three fish species, $O$. niloticus, $S$. galilaeus and $B$. bayad were the common species found in the lake. Each fish species was identified and their body weight, total length and standard length were measured. Total length (TL) and standard length (SL) were measured using the method of Lagler (1970). Total length (mm) was measured as the length of a fish from its anterior most extremity to the end of the caudal fin while standard length $(\mathrm{mm})$ was measured as the distance of the fish from its most anterior extremity (Mouth closed) to the end of the caudal peduncle. Weight were measured using top loading balance in $(\mathrm{kg})$. Mathematical expression is required to express the growth of fish. The best known growth model used in fisheries assessment is that of Von-bertalanffy, who based his formulation on physiological Characteristics of fish. The Vonbertalanffy growth model of 1957 describes growth curves as expressed by the formula. $\mathrm{L}_{\mathrm{t}}=\mathrm{L} \infty\left(\mathrm{i}-\mathrm{e}^{\mathrm{k}}\left(\mathrm{t}-\mathrm{t}_{\mathrm{o}}\right)-(1)\right.$

Where

$\mathrm{L}_{\mathrm{t}}=$ Length at age " $\mathrm{t}$ "

$L \infty=$ Asymptotic length or

Maximum attainable length approached

$\mathrm{k}=$ Rate at which the asymptotic length is

$t_{0}=A$ time in the growth history of the fish at which the fish would have been zero sized. $\mathrm{e}=$ An exponent

$\mathrm{t}=$ Age in years 
Bajopas Volume 5 Number 1 June, 2012

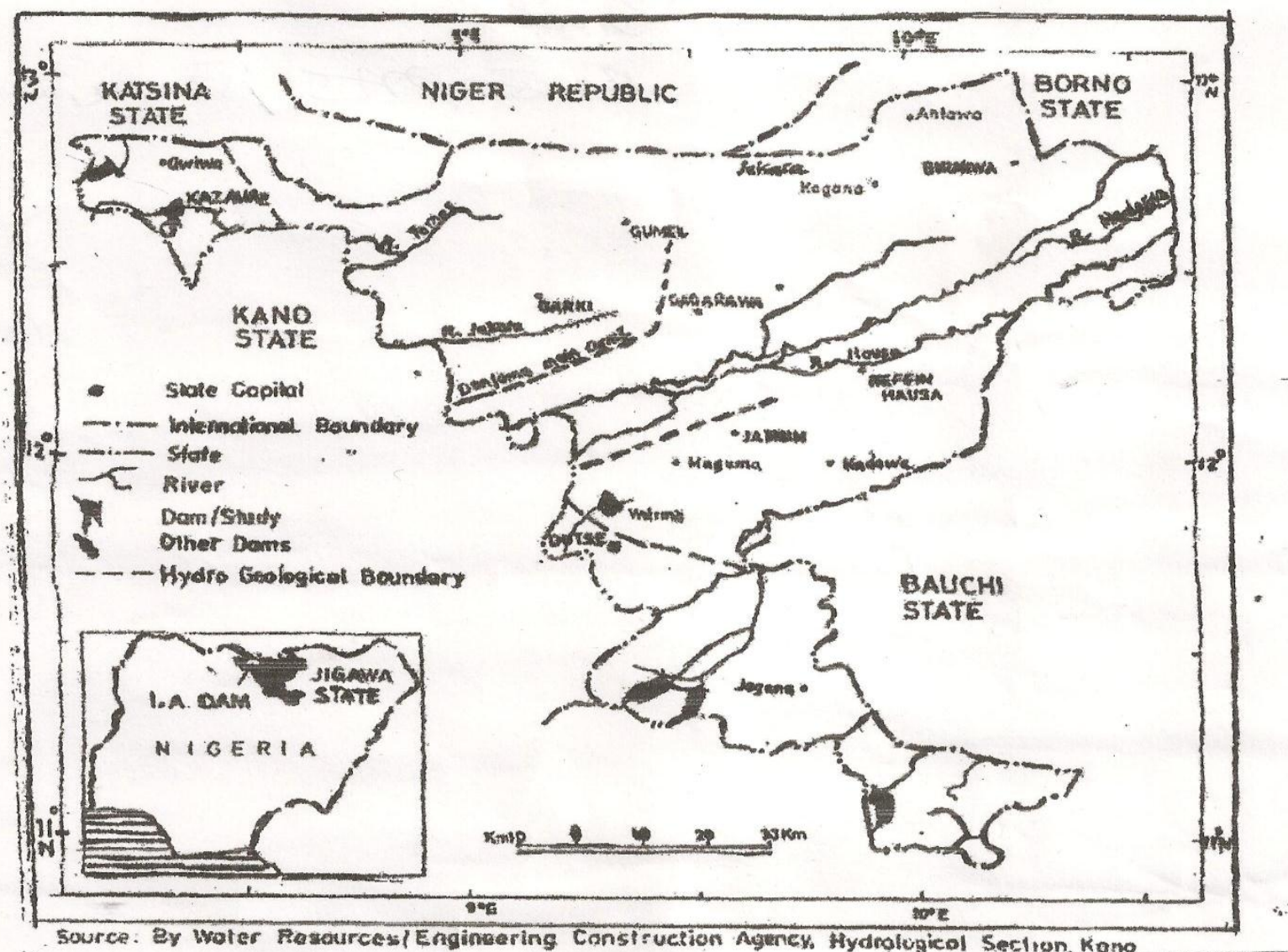

FIG 1: JIGAWA STATE DRINAGE/HYDROLOGY SHOWING LOCATION OF IBRAHTM ADAMU DAM

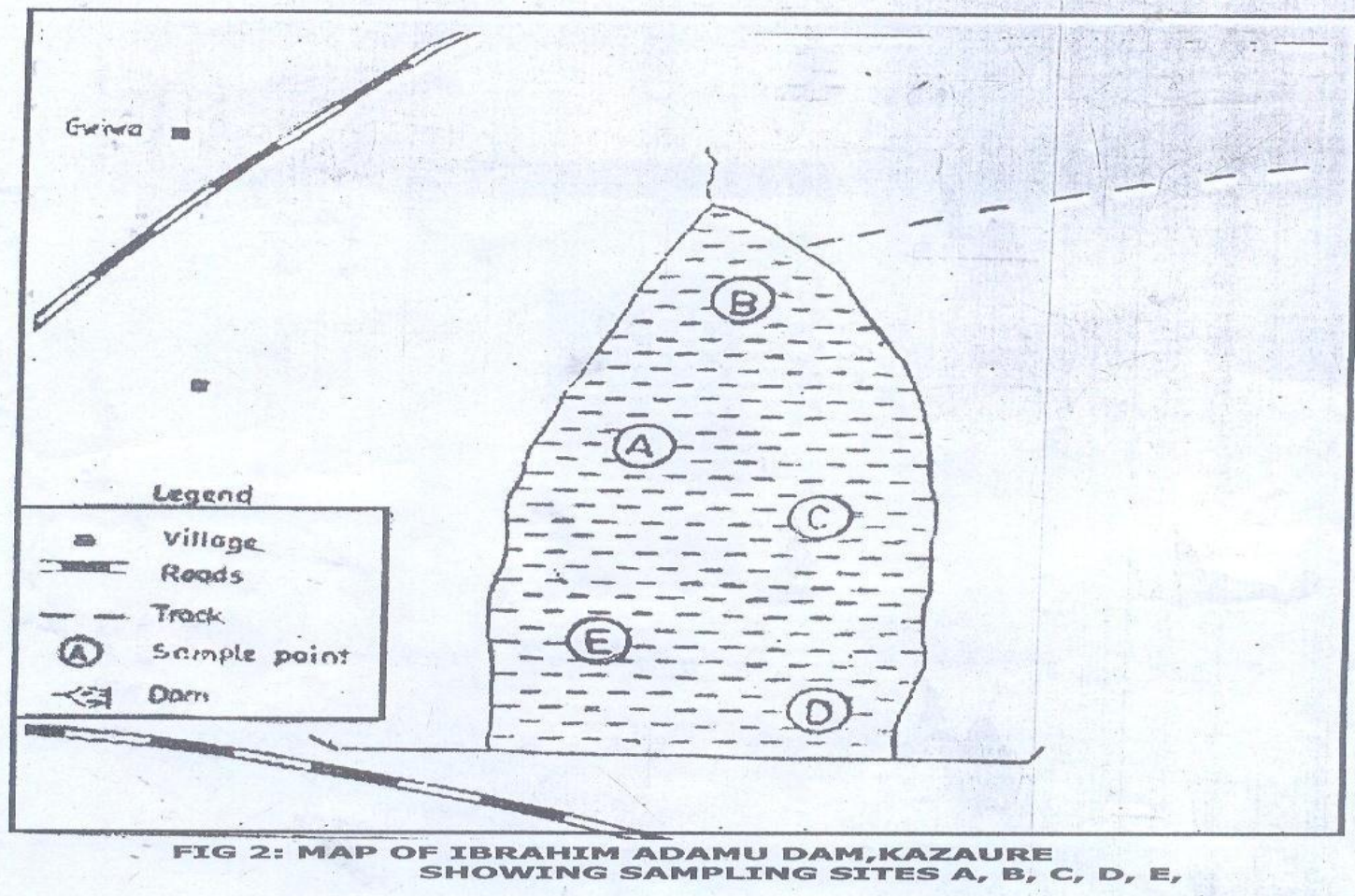


Growth curves were then fitted to the Vonbertallanfy model and tested with Walford plots (Walford, 1964; Berveton and Holt, 1957 and Ricker, 1975).

From the Walford plot, a trial L $\infty$ was obtained. Equation (1) could be re-arranged and transformed into a straight line by taking natural logarithm.

$\log _{e}\left(L_{\infty}-L_{t}\right)=\log _{e} L \infty+k t_{0}-k L_{(2)}$

From the trial $L \infty$, five values were obtained by successive addition of 1 to the trial $L \infty$ twice and successive subtraction of 1 twice from it.

Trial plots of $\log _{e}\left(L \infty-L_{t}\right)$ against age (where $L \infty$ is the trial value; $\mathrm{L}_{\mathrm{t}}=$ length at age) were performed using the method of Ricker (1975) and the line of best fit (straightest) was selected by eye or by computation from the five graphs to obtain the true $L \infty$. The gradient which is $=k$ and $k=e^{-k}$;

$\log _{\mathrm{e}} \mathrm{L} \infty+\mathrm{Kt}_{\mathrm{o}}$ is the intercept, then:

$$
t_{0}
$$

$\underline{Y \text {-axis intercept }-\log _{e} L \infty-(3)}$
Where $\mathrm{K}$ is the gradient of the line of best fit from the trial plots of $\log _{e}\left(L \infty-L_{t}\right)$ against age. Thus the Vonbertalanffy growth parameters $L \infty, K$ and $t_{0}$ in equation (1) were determined.

The growth performance index was calculated using the equation devised by Pauly (1988). $\Phi^{\prime}=\log _{10} K+2 \log _{10} L \infty-(4)$

Where $L \infty$ and $K$ are parameters of Von bertalanffy growth equation.

\section{RESULTS}

A total of 2903 species were examined during the study period and their length ranged from $20 \mathrm{~mm}-$ $220 \mathrm{~mm}$ and weight was from $20 \mathrm{~g}-200 \mathrm{~g}$. 2,013 species of $O$. niloticus were encountered and their growth parameters were $L \infty=192.5 \mathrm{~mm}, K=0.25$, $\mathrm{t}_{0}=0.12, \Phi^{\prime}=3.9668$ and $\mathrm{L} \infty=175 \mathrm{~mm}, \mathrm{~K}=0.15, \mathrm{t}_{0}=$ respectively. The example of Walford and Ricker plot for the determination of the age of male and female O. niloticus from Ibrahim Adamu lake are shown in figures $3 a-3 d$.

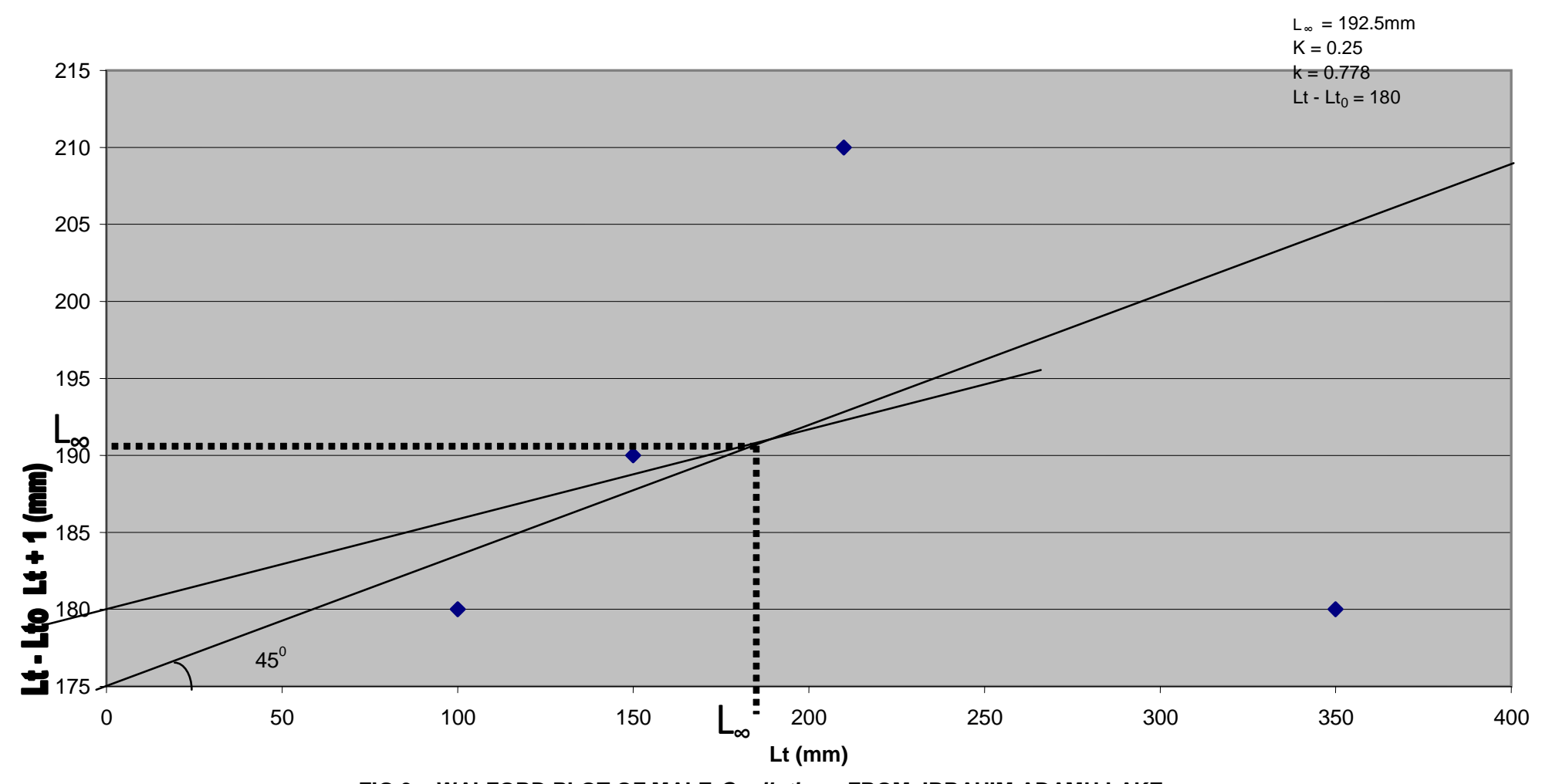

FIG 3a: WALFORD PLOT OF MALE O. niloticus FROM IBRAHIM ADAMU LAKE 
Bajopas Volume 5 Number 1 June, 2012

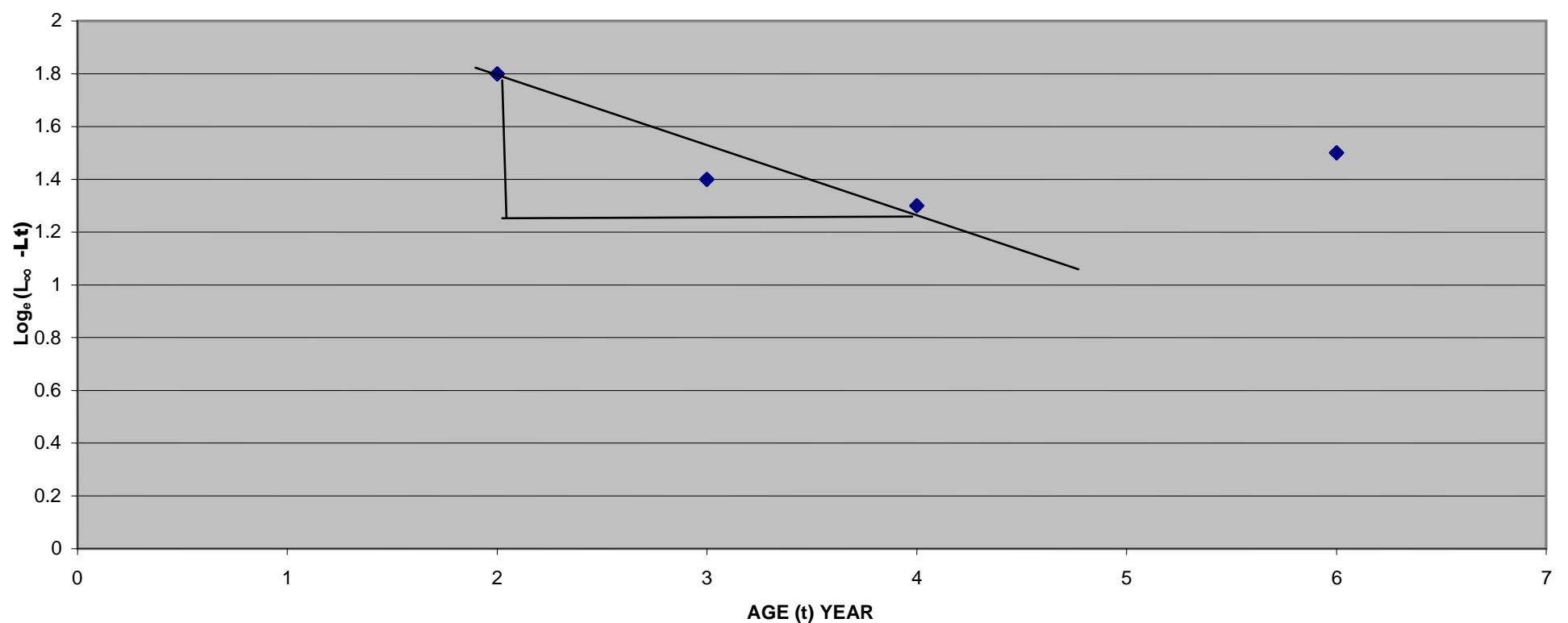

FIG 3b: RICKER PLOT FOR THE DETERMINATION OF TRUE L $\infty$ OF MALE O. niloticus FROM IBRAHIM ADAMU LAKE

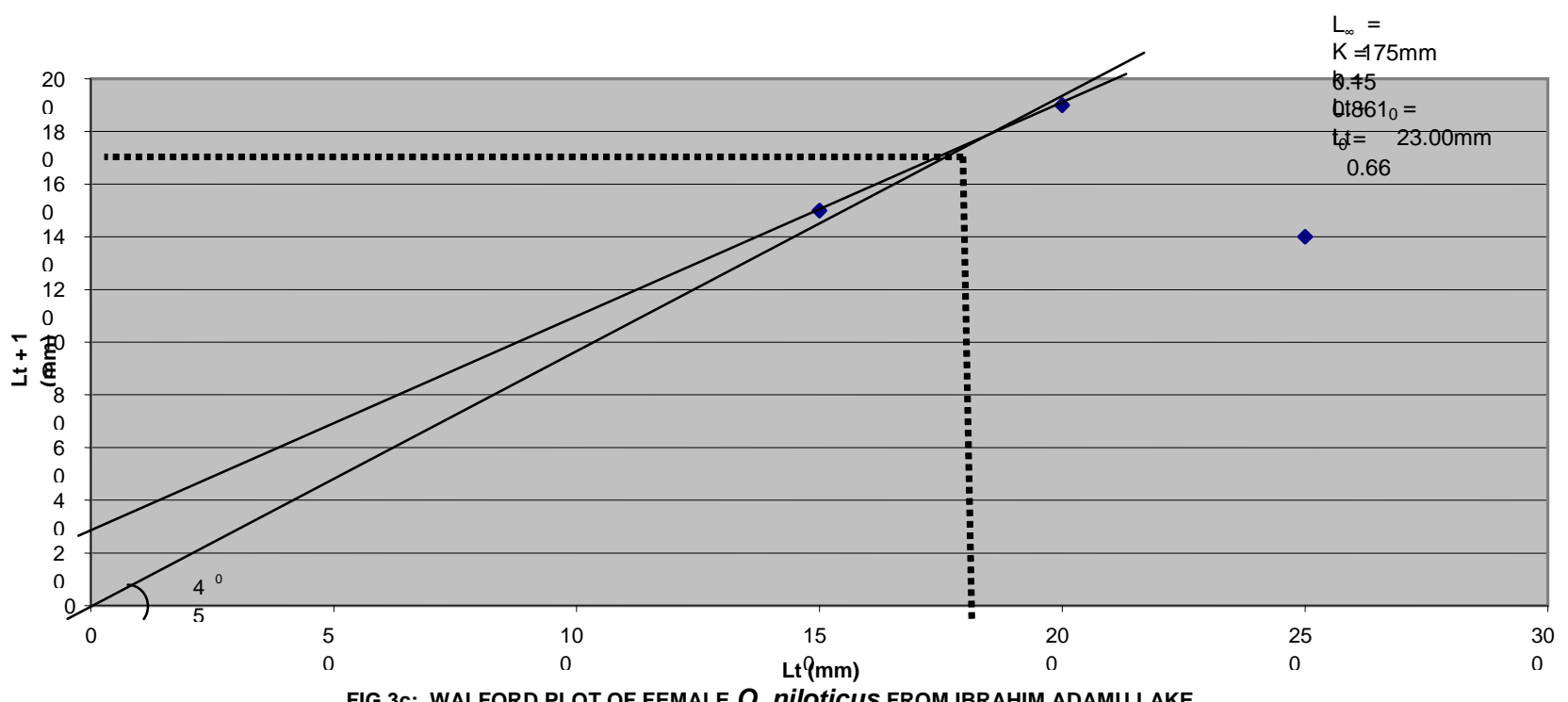

FIG 3c: WALFORD PLOT OF FEMALE 0 . niloticus FROM IBRAHIM ADAMU LAKE

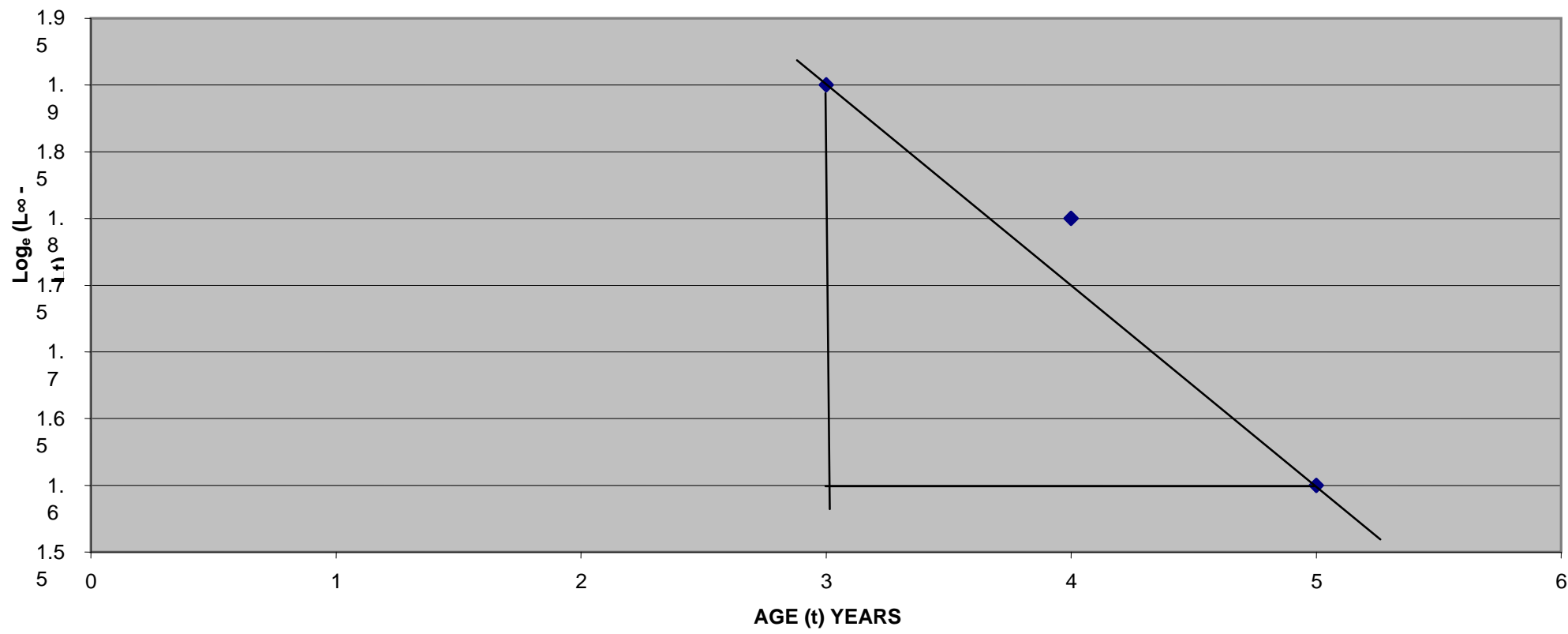

FIG 3d: RICKER PLOT FOR THE DETERMINATION OF TRUE Lœ OF FEMALE O. niloticus FROM IBRAHIM ADAMU LAKE 
A total of 337 S. galilaeus were caught and their growth parameters were $\mathrm{L} \infty=200 \mathrm{~mm}, \mathrm{~K}=0.17$, $\mathrm{t}_{\mathrm{o}}=0.30, \Phi^{\prime}=3.8222$ and $\mathrm{L} \infty=240 \mathrm{~mm}, \mathrm{~K}=0.12$, $\mathrm{t}_{0}=0.86, \Phi^{\prime}=3.8211$ for male and female species. 553 species of $N$. bayad were caught during the study period with $L \infty=520 \mathrm{~mm}, \mathrm{~K}=0.10, \mathrm{t}_{\mathrm{o}} 0.50$,
$\Phi^{\prime}=4.4320$ and $\mathrm{L} \infty=500 \mathrm{~mm}, \mathrm{~K}=0.35, \mathrm{t}_{0}=0.85$ and $\Phi^{\prime} 4.9420$ for male and female species. Tables 1 and 2 shows the growth parameters and back calculated length at age for the fish species of the lake.

Table 1: Growth indices and growth performance index $\left(\Phi^{\prime}\right)$ of the fishes from Ibrahim Adamu Lake, Kazaure, Jigawa State.

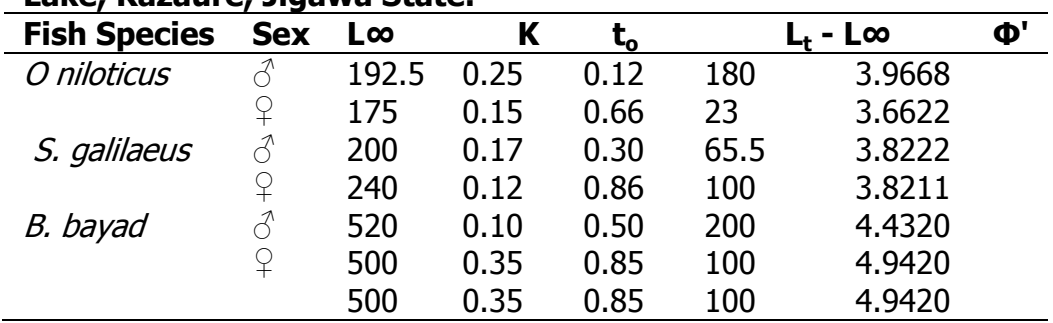

Table 2: Mean back calculated, Length at age of fishes from Ibrahim Adamu lake, Kazaure, Jigawa State.

\begin{tabular}{|c|c|c|c|c|c|c|c|c|}
\hline Species & Age & $\mathbf{L}_{1}$ & $\mathbf{L}_{2}$ & $\mathbf{L}_{3}$ & $\mathbf{L}_{4}$ & $\mathbf{L}_{5}$ & $\mathbf{L}_{6}$ & $\mathbf{L}_{7}$ \\
\hline O. niloticus & $2+$ & 52.2 & 97.5 & & & & & \\
\hline \multirow[t]{5}{*}{ ô } & $3+$ & 80 & 100 & 120 & & & & \\
\hline & $4+$ & 75 & 96 & 107 & 128 & & & \\
\hline & $5+$ & 60 & 90 & 110 & 130 & 140 & & \\
\hline & $6+$ & 60 & 80 & 100 & 110 & 140 & 160 & \\
\hline & $7+$ & 83.12 & 106.88 & 118.8 & 134.83 & 142.5 & 154.4 & 166 \\
\hline Mean & & 68.72 & 81.48 & 111.16 & 125.7 & 140.83 & 157.2 & 166 \\
\hline \multirow[t]{5}{*}{ q } & $3+$ & 65 & 92.8 & 103.1 & & & & \\
\hline & $4+$ & 90 & 110 & 120 & 130 & & & \\
\hline & $5+$ & 63 & 99 & 108 & 135 & 144 & & \\
\hline & $6+$ & 79.3 & 88.1 & 96.9 & 105.7 & 114.5 & 149.8 & \\
\hline & $7+$ & 82.6 & 90.9 & 107.4 & 105.7 & 123.9 & 140.14 & 148 \\
\hline Mean & & 75.98 & 96.2 & 107.1 & 121.6 & 127.5 & 145.1 & 148 \\
\hline \multicolumn{9}{|l|}{ S. galilaeus } \\
\hline & $2+$ & 116.3 & 13.42 & & & & & \\
\hline \multirow[t]{3}{*}{$\sigma^{\lambda}$} & $3+$ & 89.5 & 121.4 & 137.6 & & & & \\
\hline & $4+$ & 100 & 127.3 & 163.64 & 181.8 & 200.86 & & \\
\hline & $5+$ & 95.65 & 124.3 & 153.04 & 181.74 & 200.86 & & \\
\hline Mean & & 100.36 & 126.81 & 151.43 & 181.77 & 200.86 & & \\
\hline \multirow[t]{3}{*}{ ㅇ } & $2+$ & 100 & 133.33 & & & & & \\
\hline & $3+$ & 95.63 & 116.88 & 138.13 & & & & \\
\hline & $4+$ & 104.8 & 125.7 & 157.1 & 188.6 & & & \\
\hline Mean & & 100.14 & 125.30 & 147.6 & 188.6 & & & \\
\hline B. bayad & $2+$ & 169.4 & 188.2 & & & & & \\
\hline \multirow[t]{4}{*}{$\hat{0}$} & $3+$ & 307.7 & 338.5 & 369.2 & & & & \\
\hline & $4+$ & 277.9 & 301.1 & 347.4 & 393.7 & & & \\
\hline & $5+$ & 270.6 & 296.6 & 324.7 & 351.8 & 378.8 & & \\
\hline & $6+$ & 293.3 & 320 & 346.7 & 373.3 & 389.4 & 426.7 & \\
\hline \multirow[t]{2}{*}{ Mean } & & 263.78 & 288.9 & 347 & 372.9 & 384.1 & 426.7 & \\
\hline & $2+$ & 130 & 156 & & & & & \\
\hline \multirow[t]{3}{*}{ 우 } & $3+$ & 185.5 & 216.4 & 247.3 & & & & \\
\hline & $4+$ & 265.3 & 287.4 & 831.6 & 375.8 & & & \\
\hline & $5+$ & 411.4 & 445.7 & 377.1 & 411.4 & 445.7 & & \\
\hline Mean 248.1 & & 248.1 & 276.4 & 318.7 & 393.6 & 445.7 & & \\
\hline
\end{tabular}

Key: $L_{1}-L_{7}=$ mean back calculated length at age 


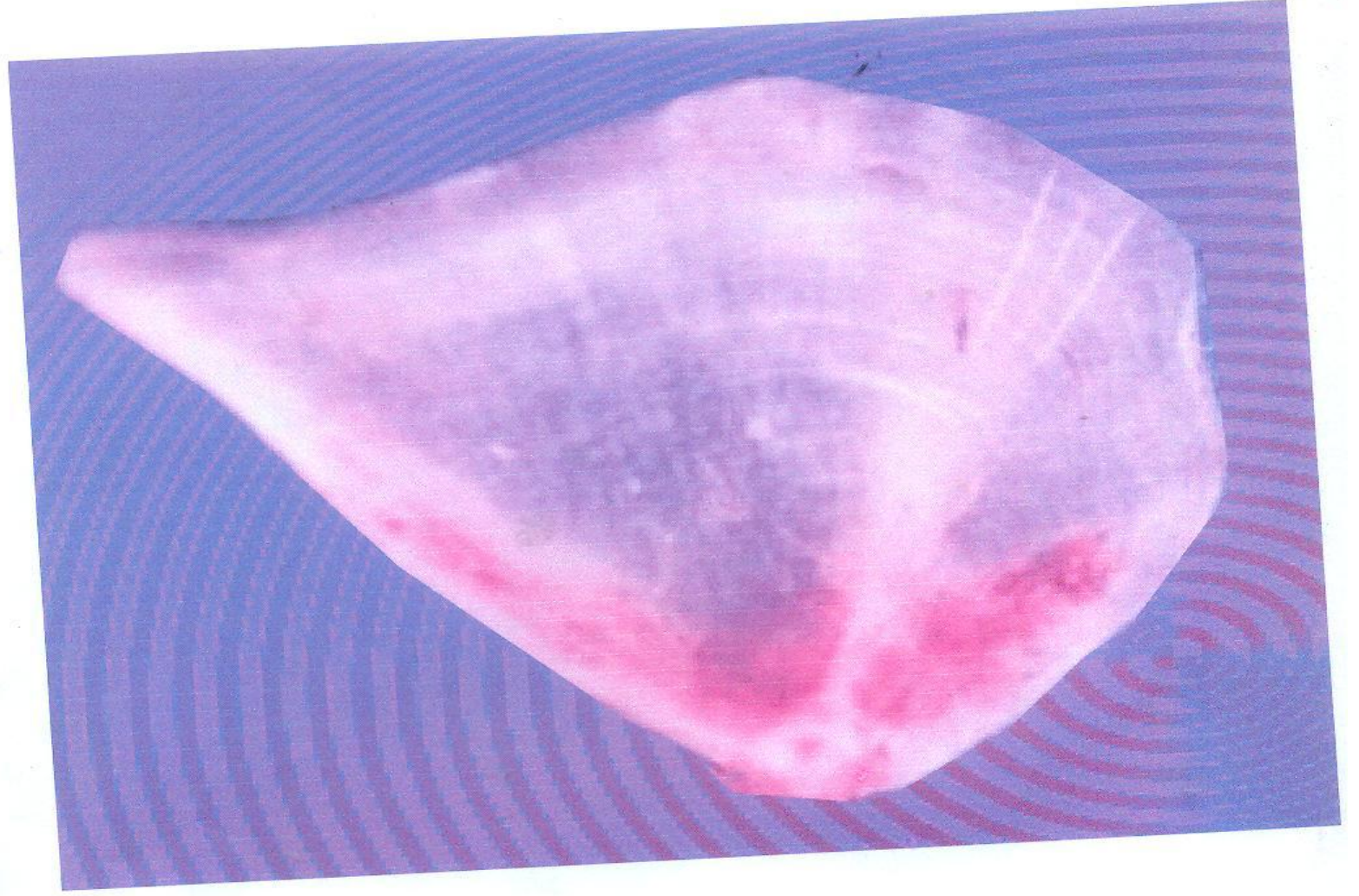

\section{Opercula bone of female $O$. niloticus from Ibrahim Adamu Lake Aged $5^{+}$}

\section{Figure 4: Operula bone of female 0 . niloticus from Ibrahim Adamu Lake aged $5^{+}$}

\section{DISCUSSION}

The Vonbertalanffy growth model (VBGM) adequately described the growth of the fish species in the lake which are of great importance in this study. In the lake, $\mathrm{K}$ values were between $0.1-0.35$. Species such as $B$. bayad had $\mathrm{K}$ value of 0.35 which shows that it has the tendency to live long and grow bigger when compared to species as demonstrated by its length $(520 \mathrm{~mm}), S$. galilaeus $(240 \mathrm{~mm})$ while $O$. niloticus had $175 \mathrm{~mm}$ as shown in table 1 . These results are comparable to those obtained by Deekae (2010) for species in Luubara creek in Ogoni Land, Niger Delta. Nigeria $\left(\mathrm{L} \infty=82.65 \mathrm{~mm}, \mathrm{~K}=1.98, \mathrm{t}_{0}=0.48, \Phi^{\prime}=3.980\right)$. Lower values were however recorded by Forest (1975); $L \infty=25.16 \mathrm{~mm}, \mathrm{~K}=0.203, \mathrm{t}_{\mathrm{o}}=0.3670$ : Rousset and Morino (1983): $\mathrm{L} \infty=23.7, \mathrm{~K}=0.380, \mathrm{t}_{0}=0.88$ and Dinis (1986); $\mathrm{L} \infty=27.710, \mathrm{~K}=0.28, \mathrm{t}_{\mathrm{o}}=-0.944$.

The growth performance index ranged from 3.622 - 4.9420. B. bayad had the highest value of 4.9420 and appear good species for aquaculture and is a preferred fish in the area and so high priced. Getabu (1992) indicated that besides the genetic make up which determines the growth potential of the species, overfishing, diet type and its utilization could affect the growth performance index of a particular species even though the growth performance index is a function of $L \infty$ (increase in Lo leads to increase in growth performance index) as shown in Table 1.0 . niloticus attains age of $7^{+}$in the lake(Table 2 ). The growth performance estimated for the fish species in the lake will allow for comparison of growth performance index among fish species in other parts of Nigeria when the estimates are available. Enin et al., (1995) suggested that the growth performance index can be used to calculate $L \infty$ and $K$ of related species when either of the parameter is available.

The growth parameters obtained for the lake are similar and this shows similar growth pattern for the fish species in the lake. 


\section{CONCLUSION AND RECOMMENDATIONS}

The growth parameters recorded for the fish species compared favourably with other results. All the values $L \infty, K, \quad t_{0}$ and $\Phi^{\prime}$ are similar and will allow for comparison of growth performance of species from similar water bodies. The higher $L \infty$ values recorded for the fish species in the lake shows that the fish species could grow to full potential when left in the

\section{REFERENCES}

Bertalanffy, L. Von (1957). Quantitative Laws in Metabolism and Growth. Q. Rev. Biol. 32: $217-231$.

Beverton, R.J.H. and Holt, S.J. (1957). On the dynamics of exploited fish population fishery invest. London. Ser. 2. 19, 533Pp.

Bilton, H.T. (1974). Effects of starvation and feeding on circulus formation on scales of young salmon of four racial origins, and of one race Koko-cho and Chinook salmon in ageing of fish. (Ed. T.B. Bagenal). Unwin Brothers, Old working Pp. $40-70$.

Deekae, S.N., J.F,N. Abowei (2010). Some Growth Parameters of Macrobrachium mcrobrachion (Herklots, 1851) from Luubara creek in Ogoni land, Niger Delta, Nigeria. Current journal of Biological Sciences 2 (5): 313 - 322.

Dinis, M.T. (1986). Quartre soleidae de Lestuaire. Reproduction of croissance, essai a elevage de solea senegalensis Kaup. Ph.D. Thesis, University of West Bretagne.

Doug,Darr.(2008).Age and Growth of Alabamas Bass. http://fishingabout.com.library/weekly/tales. htm

Enin, U.I., F. Lowenberg and T. Kunzel (1995). Population dynamics of the Estaurine prawn (Nematopalaeman hastatus, Aurivilus 1898) of the SouthEast Coast of Nigeria. Fish. Res. 26: $17-35$.

Forest, A. (1975). Le careau Di Cologolossa cuneata (moreau) sa Biologie et sap ache dans le sud du Gold de Gascogne Rev. Trav. Inst. Pech. Mart. 39 (1): $5-62$.

Getabu, A. (1992). Growth Parameters and total Mortality in Oreochromis niloticus (Linnaeus) from Nyanza Gulf, Lake Victoria. Hydrobiol. 232: $91-97$.

Gheshlagi P., Vahabnezhad A., Taghavi Motlagh S.A. (2012). Growth Parameters, Mortality rates, yield per recruit, biomass and MSY of Rutilus frisii kutum, using Length - Frequency analysis in the southern parts of the Caspian sea. Iranian Journal of Fisheries Society 11 (1): $48-62$.

Jimenez, M.P., Pineiro, C., Sobrino, I., and Ramos, F. (2000). Studies on age determination and growth pattern of the Wedge sole Dicologoglossa cuneata (Moreau, 1881) in the Spanish waters of the Gulf of Cadiz (Southwest Iberian Peninsula). Biol. Inst. Esp. Oceanogr. 17 (374). 279 - 285. lake and so the need to enhance the present system of fishing by the use of appropriate fishing technology in order to reduce overexploitation of the lake fishes. This can improve fish production which will reduce protein malnutrition to the state populace and Nigeria at large.

Kumolu - Johnson, C.A. and P.E Ndimele (2010). Length-Weight relationships and Condition Factors of Twenty-one fish species in Ologe Lagoon, Lagos, Nigeria. Asian, J. of Agric Sci, 2 (4): $174-179$.

Lagler, K.F. (1970). Capture sampling and examination of fishes in: Methods for assessment of fish production in freshwater (ed. W.E. Ricker). IBP. Handbook 3. Blackwell scientific publication, Oxford and Edinburgh, 7 - 45

Mohr, E. (1972). Bibliographic der Alters-und weahstums - Bestimmung bel Fischrj. Cons. (IEM 2 (2): $236-258$.

Ogueri, C. (2001). The fish abundance and Potentials of River Katsina - ala, Nigeria. Journal of Agriculture and Related Sciences. 1 (1): 24 30.

Pauly, D. (1988). A review of the Elefan system for analysis of Length - Frequency data in fish and aquatic invertebrates $7-34$. In D. Pauly and G.R. Morgan (Eds).

Petrakis, G. and K.I. Stergiou (1995). Weight - Length relationship for 33 fish species in Greek waters. Fisheries Research 21: 465 - 469.

Ricker, W.E. (1975). Computation and interpretation of biological statistics of fish populations. Bull. Fish. Res. Board Can, 191: 1 - 382

Rousset, J. and J.Y. Marino (1983). Croissance de Dicologoglossa cuneata (Moreau) (Teleosteen soleide) sur les cotes d'Algerie. Rapp. Comm. Int. Mer Mediter. 28 (5): 77 - 79.

Velaso, J.C.P.A., Rincen and J. Lobon - Cervia (1990). Age, growth and reproduction of the cyprinid Ratilus Lemmingii (steindochner, 1866) in the River Helebra, Central Spain. J. Fish Biol. 36: $469-488$.

Walford, L.D. (1946). A new graphic method of describing growth of Animals. Biol. Bull. Marbio. Lab. Woods Hole 90: 141 - 147.

Water Resources and Engineering Constitution Agency, Kano State. (WRECA) (1976). Water Resources Development in Kano State Bulletin on Dam Construction for Irrigation purposes. Published by (WRECA). 